\title{
PROTEIN NUTRITIONAL QUALITY OF COWPEA AND NAVY BEAN RESIDUE FRACTIONS
}

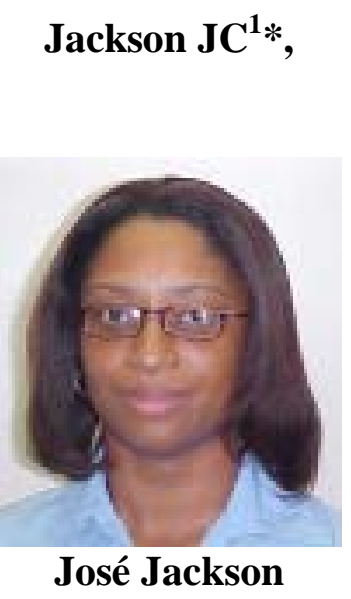

*Corresponding author email: jcjackson@yahoo.com

${ }^{1}$ Food Scientist and Deputy Director, Office of Research and Development, University of Botswana, Gaborone, Botswana.

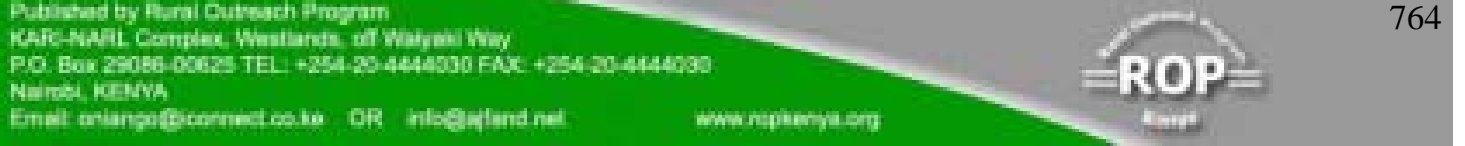




\begin{abstract}
Cereal-legume protein complementation has long been recommended as a suitable strategy for augmenting the protein quality of cereal and legume based foods. However, the use of the insoluble legume residue, following protein extraction for cereal-legume protein complementation has not been widely studied. In fact, legume residue is considered a waste by-product. The protein quality of cowpea residuewheat and navy bean residue-wheat diets was determined using in-vivo and in-vitro protein digestibility assays with an AIN-93G diet as control. The diets were fed to laboratory rats over 4 weeks. The in-vitro digestibility of the diets was assessed using the $\mathrm{pH}$ drop and $\mathrm{pH}$ stat enzymatic methods. The proximate composition, limiting amino acid profile and phytohemagglutinin activity were also determined.
\end{abstract}

All six diets had lower levels of the sulphur amino acid requirements for rats as expected but had higher than the FAO/WHO recommended levels for pre-school children. The cowpea residue diets had higher levels of limiting amino acids than the navy bean residue diets. Phytohemagglutinin activity was only detectable in the raw cowpea and navy bean samples. All cowpea residue diets, the $30 \%$ and $70 \%$ navy bean residue diets and the control diet supported growth while the $100 \%$ navy bean residue diet resulted in weight loss. The in-vitro digestibility ranged from $77.82 \%$ $84.54 \%$ and $66.51 \%-79.59 \%$ for the cowpea residue and the navy bean residue diets, respectively. These ranges were lower than the control $(98.1 \%)$ but correlated highly to those obtained using the in-vivo true protein digestibility method; $73.7 \%-87.5 \%$ and $62.6 \%-78.2 \%$, respectively.

These findings suggest that the cowpea residue diets had higher protein quality overall than the navy bean residue diets. In addition, it suggests that the 30:70 ratio of cowpea residue to wheat diet had the highest protein quality of all the 6 experimental diets. Legume residues after protein extraction could be recommended for human food if complemented with a cereal, particularly as it meets the amino acid pattern for preschool children. Finally, in-vitro assays can also be reliably used to assess the protein quality of foods.

Key words: protein quality, cowpea, navy bean. 


\section{INTRODUCTION}

Legumes have been promoted as a source of protein in countries with high rates of protein-energy malnutrition. Cowpeas and navy bean legumes are in abundance in these countries and contain proteins, carbohydrates, water-soluble vitamins and minerals [1]. The protein nutritive value of these legumes is lower than that of animal proteins. Factors contributing to the poor protein quality include poor digestibility, deficiency of sulfur amino acids and presence of non-nutritional factors (phytates, polyphenols), enzyme inhibitors (trypsin, chymotrypsin, and R-amylase), and hemagglutinins [2,3]. However, results from recent studies provide a strong basis for the beneficial health effect of legume intake in the diet [4,5,6,7]. To augment the protein quality of bean-based foods and to overcome the problem of non-nutritional factors, strategies including cereal-legume protein complementation have been used $[8,9,10,11,12]$.

Protein extraction of various legume seeds has been extensively reported in the literature $[13,14,15,16,17]$. The protein fractions are often used in various food applications based on their functional properties. The insoluble residue that remains has generally been considered a waste by-product of protein processing, and is either fed to animals or used as a soil amendment in organic farming. However, previous research on optimal legume protein extraction indicates that $35 \%$ of the total available protein remained in the residue [18]. In addition, the amino acid profiles and the protein bands after sodium dodecyl sulfate polyacrylamide gel electrophoresis (SDS PAGE) analysis of the legume residue and flour were similar [18]. Thus there is a need to evaluate the nutritional quality of legume residues after protein extraction.

The objective of this study was to determine the protein quality of cowpea residuewheat and navy bean residue-wheat diets, determine its suitability as a food for humans and to assess the applicability of using less expensive in-vitro assays to assess protein nutritional value of foods.

\section{METHODOLOGY}

\section{Materials}

Mature dry seeds of cowpea (Vigna unguiculata) and navy beans (Phaseolus vulgaris) were obtained from Bayside Best Beans LLC, Sebewaing, Michigan and were stored in a walk-in cooler in the Food Processing Laboratory in the Department of Food Science and Human Nutrition at Michigan State University (MSU) at $4^{\circ} \mathrm{C}\left(39^{\circ} \mathrm{F}\right)$.

\section{Protein fractionation procedure}

The cowpea and navy bean seeds were milled in a Fitzpatrick mill (Model D Comminuting Machine, Fitzpatrick Co., Chicago, IL) using a sieve size of $1.59 \mathrm{~mm}$. A series of 4 extractor baskets (200 mesh) were used in the extraction process to separate the residue from protein extract. Twenty liters of distilled water and $2 \mathrm{~kg}$ of bean flour were added to the extractor basket, and the $\mathrm{pH}$ adjusted to 10 with $400 \mathrm{ml}$

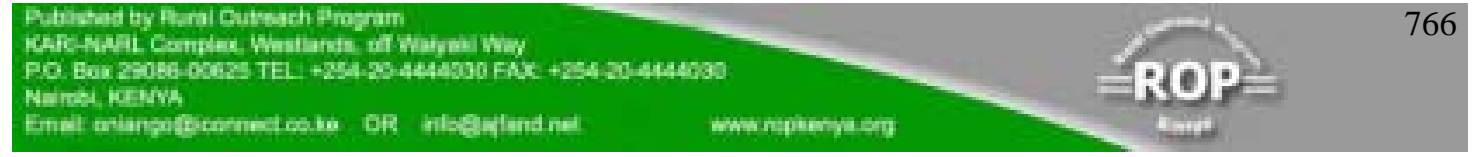


$1 \mathrm{~N}$ sodium hydroxide $(\mathrm{NaOH})$. The mixture was re-circulated for 60 minutes at $25^{\circ} \mathrm{C}$, to ensure complete extraction, and then passed through a series of cheesecloth to separate any fibrous matter that passed through the basket. The flour was re-extracted twice under the same conditions until there were three extracts produced (Figure 1). The insoluble residue was collected and stored under refrigerated conditions $\left(4^{\circ} \mathrm{C}\right)$.

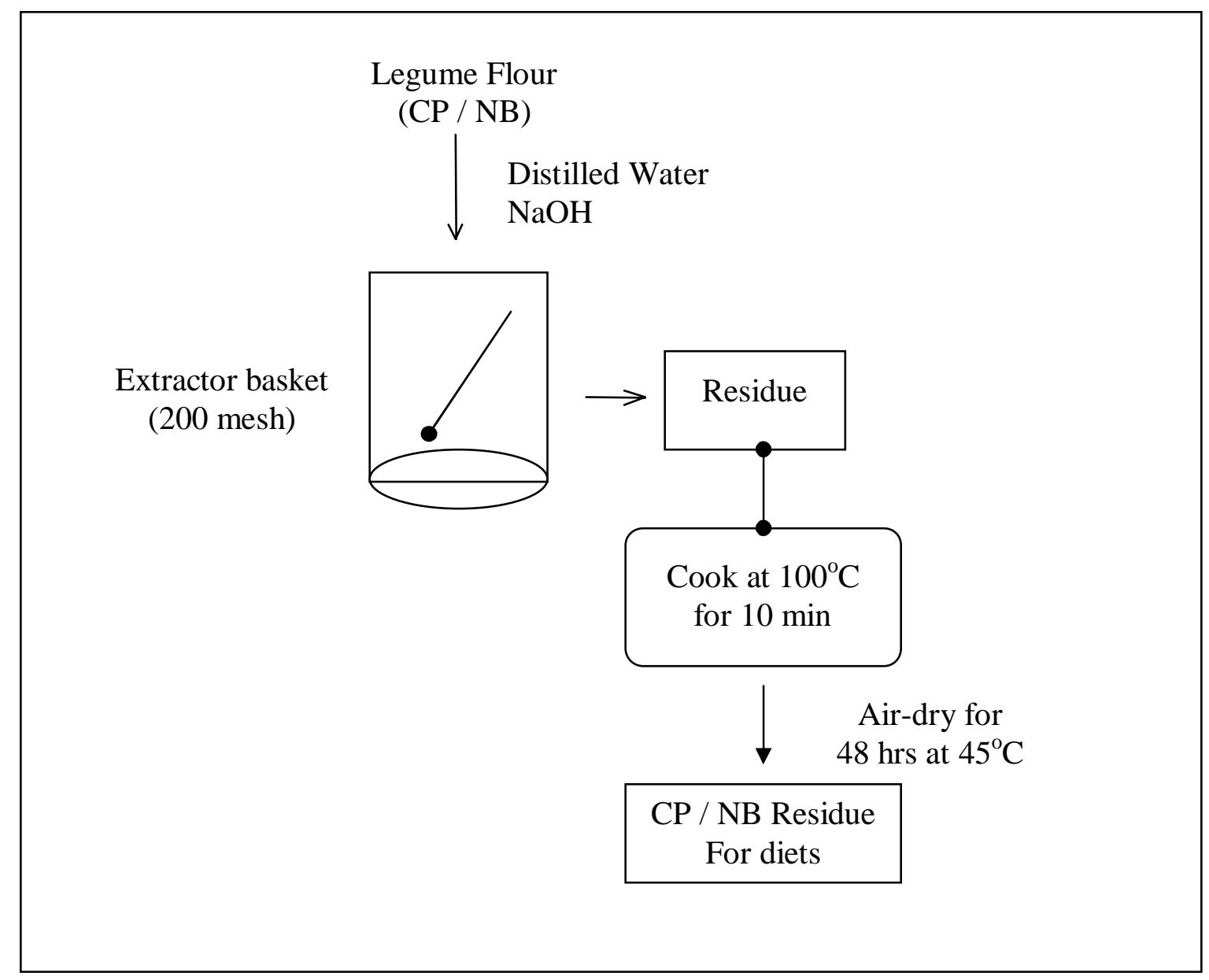

Figure1: Processing scheme for production of cowpea (CP) residue and navy bean $(\mathrm{NB})$ residue.

Diet preparation and analysis

The raw residue that remained after protein extraction of cowpea and navy bean flour was cooked at $100^{\circ} \mathrm{C}$ for $10 \mathrm{~min}$. to inactivate hemagglutinin, and then air-dried for 48 hours at $45^{\circ} \mathrm{C}$ (Figure 1). The cooked residue was then stored at $4^{\circ} \mathrm{C}$.

Experimental diets were prepared based on the composition of the control diet, American Institute of Nutrition (AIN), AIN-93G diet. The AIN-93G is a rodent

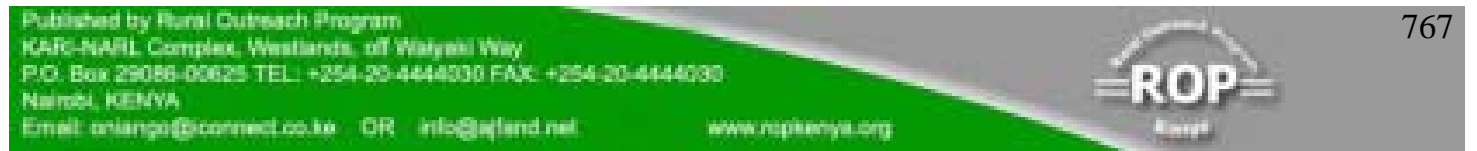


research diet specifically formulated for growth, pregnancy, and lactation. All of the diets contained a source of protein, fat, fiber, micronutrients, starch, choline bitartrate, and butylated hydroxytoluene. A $2 \%$ albumin (2\%ALB) diet was used as an estimate of metabolic fecal nitrogen. All of the ingredients except oil were mixed in a mixing bowl at the slowest speed to reduce elevated dust levels. The oil component was added slowly and the diets mixed for an additional $25 \mathrm{~min}$ at slow speed. The diets were stored at $4^{\circ} \mathrm{C}$ in tightly sealed plastic containers prior to use.

Moisture, crude fiber, fat, ash, and nitrogen content of the experimental diets were determined according to standard AOAC methods [19]. Crude protein was determined using the nitrogen to protein factor of 5.7 for the legume diets and 6.25 for the modified AIN-93G and 2\%ALB diets. The amino acid composition was analyzed at CN Laboratories (Courtland, MN) using the Waters Pico-Tag® method as reported by Bidlingmeyer et al. [20]. Cysteine and methionine were analyzed after performic acid oxidation and determined as cysteic acid and methionine sulfone, respectively. Tryptophan was hydrolyzed with methanosulfonic acid [21].

Screening for phytohemagglutinin was assessed using the method reported by Occeña with anti-Phaseolus vulgaris lectin as immunogen and Phaseolus vulgaris lectin as reference [22]. The formation of a precipitate was determined subjectively after an hour, and indicated the presence of lectin. The results were recorded using the following notation: + indicates the presence of a precipitate; number of + indicates the degree of precipitation (++++ strong positive, + slight positive).

\section{In-vitro protein digestibility assay}

In-vitro digestibility of the experimental diets was assayed using two multi-enzyme methods. The four-enzyme $\mathrm{pH}$ Drop method, consisting of trypsin, chymotrypsin, peptidase and protease, where \% digestibility $=234.84-22.56(\mathrm{X})$, and $\mathrm{X}=\mathrm{pH}$ at 20 min [19]. The second method used the three-enzyme $\mathrm{pH}$ Stat method, consisting of trypsin, chymotrypsin, and peptidase, where $\%$ digestibility $=76.14+47.77 \mathrm{~B}$, and $\mathrm{B}$ $=m l 0.1 \mathrm{~N} \mathrm{NaOH}$ added [23].

\section{In-vivo protein digestibility assay}

Twenty male weanling Sprague-Dawley rats (Harlan Sprague Dawley Inc., IN), housed at the Animal Facility of the Department of Food Science and Human Nutrition, Michigan State University (MSU), were used in the in-vivo feeding study over a period of 4-weeks. All experimental procedures were approved and conducted in accordance with the protocol of the MSU All University Committee on Animal Use and Care (AUCAUC) by staff that was trained to carry out such procedures.

The rats were ranked by weight and diets randomly assigned over the four-week period so that none of them received the same diet twice. They were housed in individual cages and given free access initially to the $2 \%$ ALB diet for 24 hours to ensure their adaptation to the experimental conditions. The experimental diets and water were then fed ad libitum for seven days to groups of ten rats in a completely randomized design. The diets fed included 30CP - 30\% cowpea protein and $70 \%$

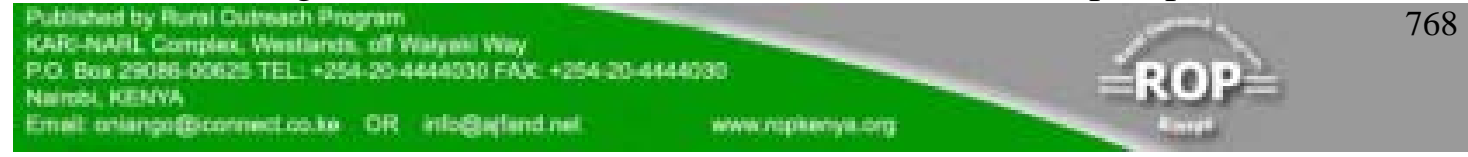


whole wheat flour protein; 70CP - 70\% cowpea protein and 30\% whole wheat flour protein; 100CP - 100\% cowpea protein; 30NB - 30\% navy bean protein and $70 \%$ whole wheat flour protein; $70 \mathrm{NB}-70 \%$ navy bean protein and $30 \%$ whole wheat flour protein; 100NB - 100\% navy bean protein; and AIN - Modified AIN-93G, the control.

The animals were weighed daily, food intake was measured, and spilled food and fecal matter collected, air-dried and weighed between days three and seven. Fecal samples were ground in a mortar and stored at $4^{\circ} \mathrm{C}$ prior to protein analysis. True protein digestibility for each diet was calculated using a standard formula [24].

\section{Statistical analysis}

The mean and standard deviation of the estimated constituents were computed. Analysis of variance (ANOVA) was applied to test the differences in food intake, rat growth and protein digestibility among the legume residue diets by Fisher's least significant difference (LSD) in Stat View (SAS Institute Inc.). The differences were considered significant at a 5\% level. The correlation between the in-vitro and in-vivo protein digestibility assays was also determined.

\section{RESULTS}

\section{Composition and phytohemagglutinin activity of diets}

The composition of each cowpea and navy bean residue diet is shown in Table 1 . Diets 1 - 6 contained a combination of 30\%,70\%, 100\% cowpea residue or navy bean residue protein supplemented with $70 \%, 30 \%, 0 \%$ wheat flour protein, respectively. Diet 7 was $2 \%$ albumin to estimate metabolic fecal nitrogen and diet 8 was the control modified AIN-93G diet with casein as the protein source. Each diet contained approximately $9-12 \%$ protein, $13-17 \%$ fiber, $10-15 \%$ fat, $3.5-7 \%$ ash, $4-6 \%$ moisture, and carbohydrate of $50-69 \%$.

The composition of the limiting essential amino acids in cereals and legumes, that is, lysine, tryptophan, cysteine + methionine, is shown in Table 2. All cowpea residue and navy bean residue diets had lower amounts of the limiting essential amino acids than the control but most of the cowpea residue diets were not significantly different than the control $(\mathrm{p}<0.05)$. The cowpea residue diets had higher amounts of the limiting essential amino acids than the navy bean residue diets and were significantly different from them $(\mathrm{p}<0.05)$.

Phytohemagglutinin or lectin activity of the cooked and uncooked residues and each diet is shown in Table 3. Activity was detectable only in the raw cowpea and navy bean samples. There was no detectable activity in the cooked residue samples or the control.

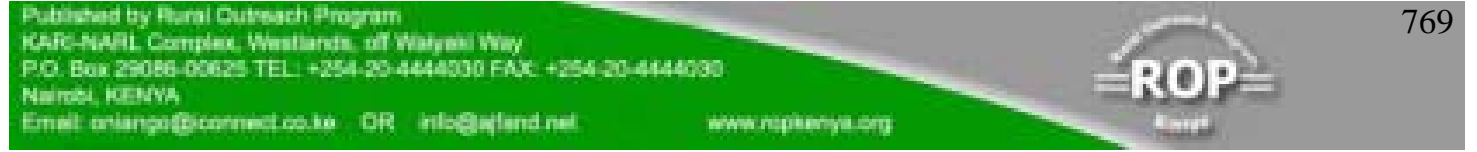




\section{In-vitro and in-vivo protein digestibility}

In-vitro protein digestibility determined by the $\mathrm{pH}$ Stat and $\mathrm{pH}$ Drop methods are shown in Figure 2. In all cases, digestibility was highest using the $\mathrm{pH}$ Stat method. The average values for cowpea residue diets ranged from $80.30 \%-84.54 \%$ and $77.82 \%-79.93 \%$ for the $\mathrm{pH}$ stat and $\mathrm{pH}$ drop methods, respectively. The average values for navy bean residue diets ranged from $79.28 \%-79.59 \%$ and $66.51 \%$ $74.89 \%$ for the $\mathrm{pH}$ stat and $\mathrm{pH}$ drop methods, respectively. All of the cowpea residue diets had higher digestibility than the navy bean residue diets using both in-vitro assays. As the legume protein concentration in the diet increased, digestibility decreased for all diets. There was a highly significant difference $(p<0.0001)$ in digestibility between the cowpea residue and the navy bean residue diets. Cowpea residue and navy bean residue diets were also different from the control AIN-93G diet $(p<0.05)$. The digestibility of the navy bean residue diets was not significantly different $(\mathrm{p}<0.05)$.

The type of diet fed to the rats appeared to have a highly significant effect on rat growth ( $\mathrm{p}<0.0001)$. All cowpea residue diets, $30 \%$ and $70 \%$ navy bean residue diets and the control supported rat growth, while those fed the $100 \%$ navy bean residue diet decreased in weight. However, rats fed on the experimental diets grew more slowly than those fed the control diet (Table 4). The food intake of all cowpea residue diets was greater than that observed for all navy bean residue diets and the control. Navy bean residue diets were the least consumed of all the diets (Table 4).

The average in-vivo true protein digestibility for cowpea residue, navy bean residue and the control diets was $73.7 \%-87.5 \%, 62.6 \%-78.2 \%$, and $98.1 \%$, respectively (Figure 2). All cowpea residue diets had higher in-vivo digestibility than the corresponding navy bean residue diets. The 30\% cowpea residue diet was the only experimental diet whose digestibility was not significantly different from the control $(\mathrm{p}<0.05)$.

The in-vitro protein digestibility assays correlated well with data for in-vivo assays as shown in previous studies [25,26,27]. Significant correlations $(p<0.05)$ were obtained for $\mathrm{pH}$ stat $\mathrm{vs} \mathrm{pH}$ drop (0.73), for $\mathrm{pH}$ stat vs in vivo (0.86) and for $\mathrm{pH}$ drop vs in vivo (0.89). 


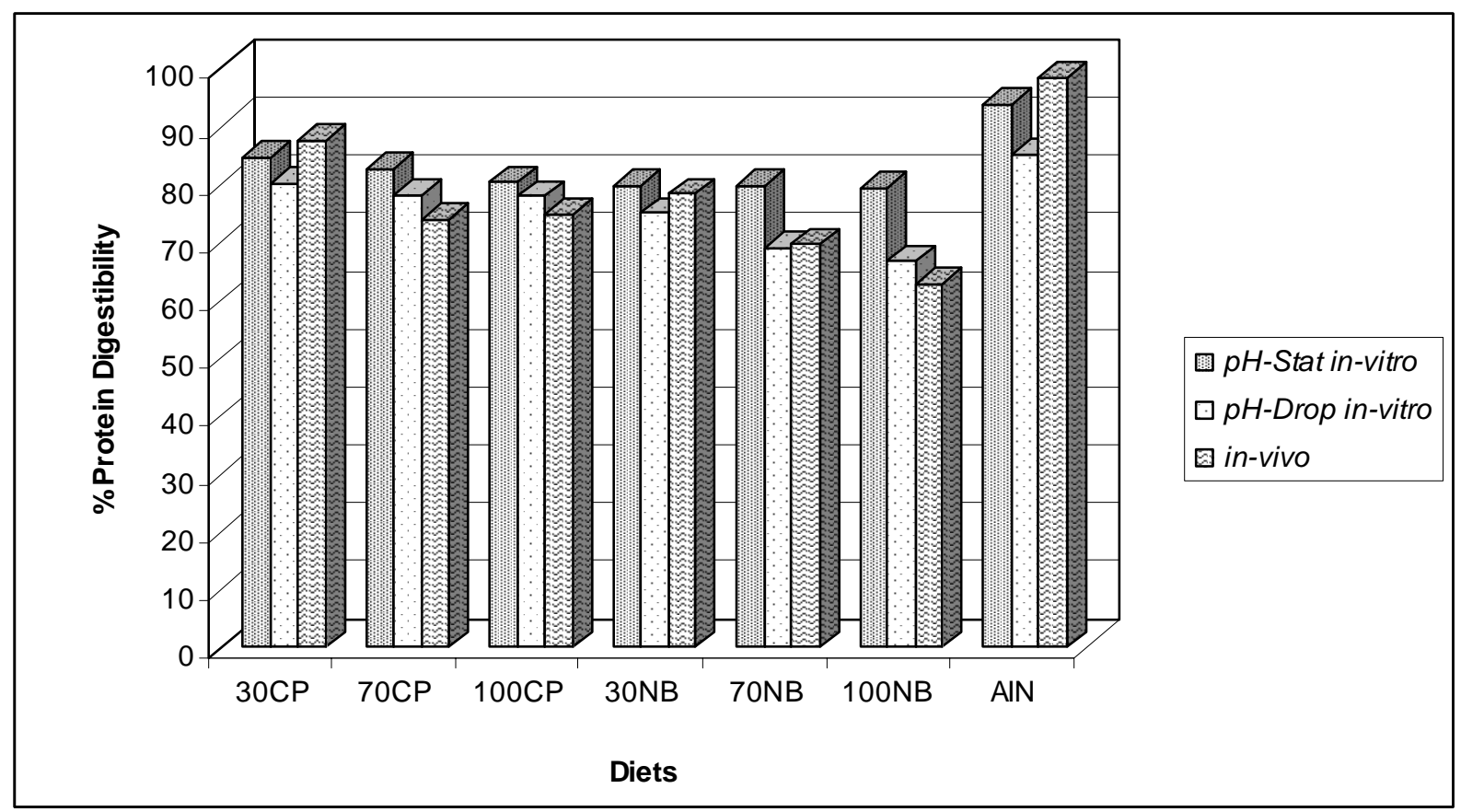

Figure 2: In-vitro and in-vivo protein digestibility of wheat supplemented cowpea residue and navy bean residue diets ( $\mathrm{pH}$ Stat vs. $\mathrm{pH}$ Drop, $\mathrm{r}=0.78$; in-vivo vs. pH Stat, $\mathrm{r}=0.86$; in-vivo vs. pH Drop, $\mathrm{r}=0.89$ ). 


\section{DISCUSSION}

Phytohemagglutinin or lectin was not detected in the cooked residues or the diets as these had been cooked before consumption. This is consistent with previous research reported on phytohemagglutinin activity, which indicated that a heat treatment of $100^{\circ} \mathrm{C}$ for 10 minutes was sufficient to inactivate all activity [22,28]. However, both cowpea residue and navy bean residue diets were still less digestible than the control in particular the navy bean residue diets. Phytohemagglutinin has been reported to reduce protein digestibility due to its interference with intestinal surfaces and enzyme activity [28]. This suggests that other non-nutritive factors such as protease inhibitors that interfere with the action of proteolytic enzymes, tannins and phytates that complex with proteins and increase their resistance to proteolytic degradation [29] may still be present in the diets. These, however, were not analysed in this study. In addition, a quantitative method to assess phytohemagglutinin activity would have shown differences between the activity of navy bean and cowpeas diets and explain further the digestibility observed.

As expected, the diets that had higher cowpea or navy bean content were deficient in the sulphur amino acids, while those with higher wheat content were deficient in lysine. The concentration of limiting essential amino acids including lysine, tryptophan and cysteine + methionine in the cowpea residue diets was higher than in the navy bean residue diets. All cowpea residue diets had higher than the suggested pattern of these limiting amino acid requirements for pre-school children (2-5 yrs). For the navy bean residue diets, only the $30 \%$ diet had higher than the suggested pattern for pre-school children; tryptophan was lower for the $70 \%$ and $100 \%$ navy bean residue diets. As expected the experimental diets had lower than the sulphur amino acids pattern for rats because of the high sulphur requirement by rats due to their body hair. For both cowpea and navy bean residue diets, the 30\% legume, $70 \%$ cereal diet had the better pattern of amino acid composition to support growth. This supports the findings in the literature that the 30:70 ratio for legume cereal complementary diets had a better amino acid composition than either legume or cereal alone $[29,30]$.

The lower food consumption observed with the navy bean residue diets as compared to the cowpea residue diets is consistent with previous research reported, which found that rats fed diets containing low-quality protein coincided with lower food intakes than those consuming high-quality proteins [30]. Diets with higher levels of the legume residue (100\% diets) also had lower food intake and could be due to reduced palatability [30]. Consequently, those rats with low food intakes also had poor growth over the feeding period. Complementing the legume residues with wheat improved the food intake and growth of the rats.

Although the protein digestibility of all the experimental diets were lower than the control diet, the $30 \%$ legume / wheat supplemented diets showed relatively high

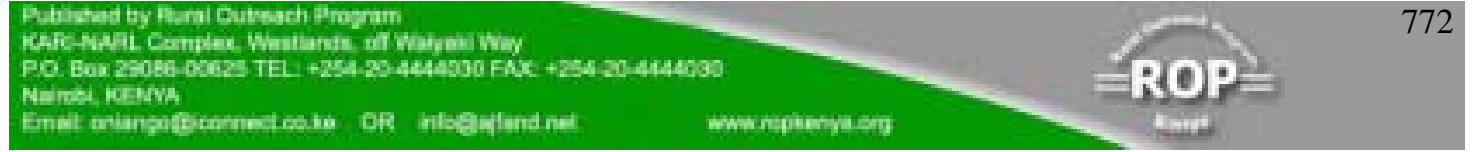


digestibility ( $78-88 \%$ ), particularly the cowpea residue diets, using both in-vitro and in-vivo assays. These findings have been demonstrated previously with cowpea $[9,29]$.

\section{CONCLUSION}

Both amino acid composition and digestibility measurements are considered necessary to predict accurately the protein quality of foods. Since the cowpea residue diets had both higher protein digestibility and higher amino acid composition than the navy bean residue diets, it is feasible to conclude that the cowpea residue diets had higher protein quality than the navy bean residue diets. As with previous studies on legume-cereal complementation, the $30 \%$ cowpea residue diet had the highest protein quality. The cowpea and navy bean residue diets appeared to meet the limiting amino acid requirements for pre-school children and could therefore be used as human food if complemented with a cereal like wheat. In addition, based on the high correlation between the two types of assays, less expensive in-vitro assays were a suitable tool to assess the nutritional value of foods as compared to in-vivo assay. 
Table 1: $\quad$ Cowpea (CP) and Navy bean (NB) protein experimental diet composition (g/100 g).

\begin{tabular}{lcccccccc}
\hline & \multicolumn{7}{c}{ Diets } \\
\cline { 2 - 9 } Ingredients & $70 N B$ & $70 C P$ & $30 N B$ & $30 C P$ & $100 N B$ & $100 C P$ & $2 A l b$ & Control \\
\hline Whole Wheat flour (WW) & 27.20 & 27.20 & 63.46 & 63.46 & - & - & - & - \\
Navy bean Residue (NB) & 45.90 & - & 19.67 & - & 65.57 & - & - & - \\
Cowpea Residue (CP) & - & 49.05 & - & 21.02 & - & 70.08 & - & - \\
Albumin & - & - & - & - & - & - & 2.00 & - \\
Casein & - & - & - & - & - & - & - & 10.00 \\
Corn oil & 10.75 & 10.75 & 10.75 & 10.75 & 10.75 & 10.75 & 10.75 & 10.75 \\
Fiber & 1.03 & 0.47 & 0.24 & 0.00 & 1.63 & 0.82 & 13.43 & 13.43 \\
Mineral mix & 3.50 & 3.50 & 3.50 & 3.50 & 3.50 & 3.50 & 3.50 & 3.50 \\
Vitamin mix & 1.00 & 1.00 & 1.00 & 1.00 & 1.00 & 1.00 & 1.00 & 1.00 \\
Choline bitartrate & 0.25 & 0.25 & 0.25 & 0.25 & 0.25 & 0.25 & 0.25 & 0.25 \\
Butylated hydroxytoluene & 0.0014 & 0.0014 & 0.0014 & 0.0014 & 0.0014 & 0.0014 & 0.0014 & 0.0014 \\
Arrowroot Starch & 10.37 & 7.78 & 1.12 & 0.02 & 17.30 & 13.61 & 69.07 & 61.07 \\
\hline
\end{tabular}

Table 2: Relative hemagglutinin activity of Cowpea (CP) and Navy bean (NB) residues and experimental diets.

\begin{tabular}{lll}
\hline Samples & CP & NB \\
\hline $30 \%$ Diet & ND & ND \\
$70 \%$ Diet & ND & ND \\
$100 \%$ Diet & ND & ND \\
Raw Residue & +++ & +++ \\
Cooked Residue & ND & ND \\
\hline
\end{tabular}

ND - not detectable; Control diet had no detectable activity 
Table 3: Essential amino acids in cowpea and navy bean diets compared with the recommended essential amino acid patterns for infants and rats (g/ $100 \mathrm{~g}$ protein).

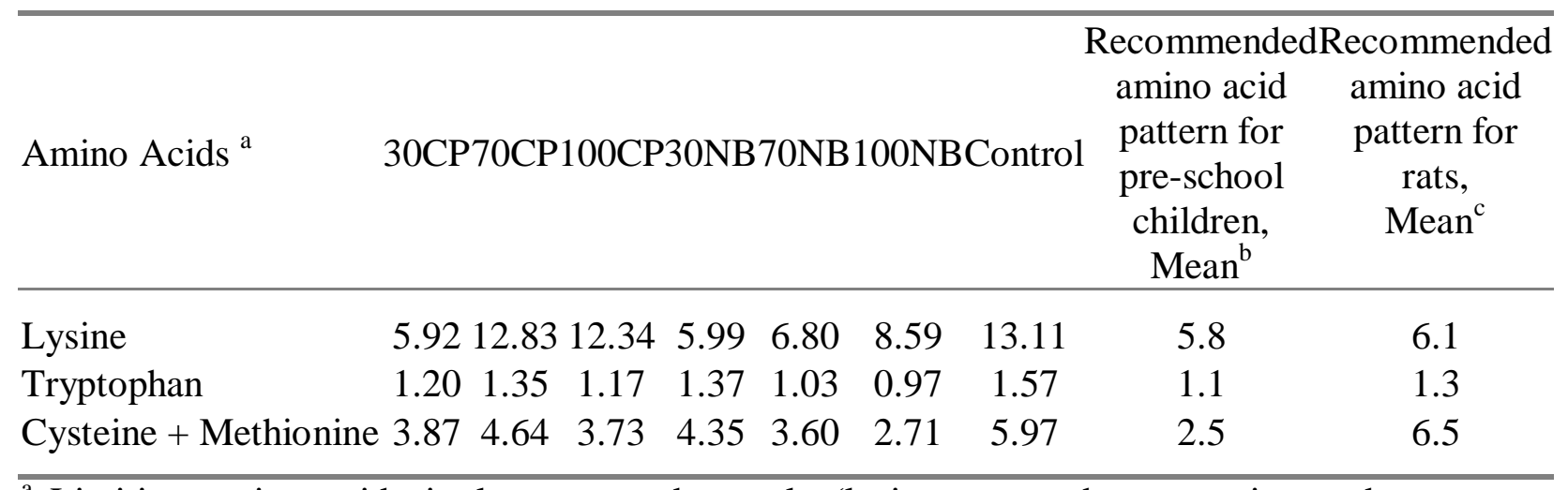

${ }^{a}$ Limiting amino acids in legumes and cereals (lysine; tryptophan; cysteine and methionine).

${ }^{\mathrm{b}} \mathrm{FAO} / \mathrm{WHO}(1991)$;

${ }^{\mathrm{c}} \mathrm{NRC}, 1995$.

Table 4: $\quad$ Food Intake and Rat Growth over the Feeding Period.

\begin{tabular}{lcc}
\hline Diets & Food Intake $(\mathrm{g})$ & Rat Growth $(\mathrm{g})$ \\
\hline $30 \mathrm{CP}$ & $75.65 \pm 12.37 \mathrm{a}$ & $(+) 42.07$ \\
$70 \mathrm{CP}$ & $69.44 \pm 8.86 \mathrm{a}, \mathrm{b}$ & $(+) 39.09$ \\
$100 \mathrm{CP}$ & $50.11 \pm 9.00 \mathrm{c}$ & $(+) 18.95$ \\
$30 \mathrm{NB}$ & $46.21 \pm 11.06 \mathrm{c}, \mathrm{d}$ & $(+) 8.46$ \\
$70 \mathrm{NB}$ & $45.01 \pm 11.27 \mathrm{c}, \mathrm{d}, \mathrm{e}$ & $(+) 3.81$ \\
$100 \mathrm{NB}$ & $27.06 \pm 7.60 \mathrm{f}$ & $(-) 11.76$ \\
Control & $48.03 \pm 10.85 \mathrm{c}, \mathrm{d}, \mathrm{e}, \mathrm{h}$ & $(+) 11.91$
\end{tabular}

Means within a column with the same letters are not significantly different ( $\mathrm{p}<$ $0.0001)$

(+) increase in growth; (-) decrease in growth.

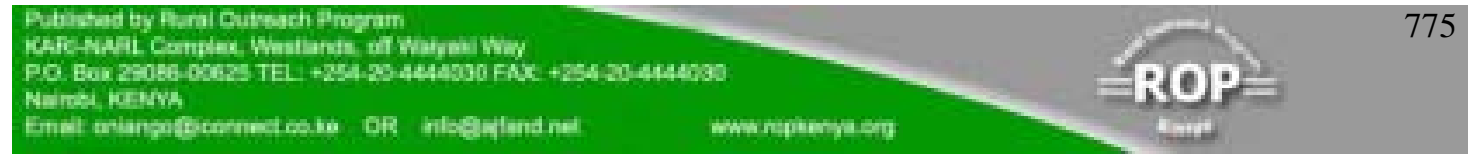




\section{REFERENCES}

1 Friedman $\mathbf{M}$ Nutritional value of proteins from different food sources. A review. J. Agric. Food Chem. 1996; 44: 6-29.

2 Gwiazda S, Schwenke KD and A Rutkowski Isolation and partial characterization of proteins from pea (Pisum sativum L.). Nahrung. 1980; 24: 939-950.

3 Evans $\mathbf{M}$ and $\mathbf{D}$ Boulter Crude protein and sulphur amino acid contents of some commercial varieties of peas and beans. J. Sci. Food Agric. 1980; 31: $238-242$.

4 Lee YP, Puddey IB and JM Hodgson Protein, fibre and blood pressure: potential benefit of legumes. Clin. and Exper Pharm and Phys. 2008; 35: (4), 473-476.

5 Villegas R, Gao Y, Yang G, Li H, Elasy TA, Zheng W and XO Shu Legume and soy food intake and the incidence of type 2 diabetes in the Shanghai Women's Health Study. Amer J. of Clin Nutr. 2008; 87: (1), 162167.

6 Hangen L and MR Bennink Consumption of Phaseolus vulgaris (black beans or navy beans) reduces colon cancer in rats. Nutr Cancer. 2002; 44: (1), 60-65.

7 Zulet MA and A Martinez Mediterranean diet: legumes and cholesterolemia. ReVista Chilena de Nutrición. 2001; 28: 312-320.

8 Hernandez M, Montalvo I, Sousa V and A Sotelo The protein efficiency ratios of 30:70 mixtures of animal: vegetable proteins are similar or higher than those of the animal foods alone. J. Nutr. 1995; 126: 574-581.

9 Philips RD, McWatters KH, Chinnan MS, Hung Y, Beucha LR, SefaDedeh S, Sakyi-Dawson E, Ngoddy P, Nnanyelugo D, Enwere J, Komey NS, Liu K, Mensa-Wilmot Y, Nnanna IA, Okeke C, Prinyawiwatkul W, FK Saalia FK Utilization of cowpeas for human food . Field Crops Res. 2003; 82:2-3, 193-213.

10 Nnanna IA and RD Phillips Protein and starch digestibility and flatulence potential of germinated cowpeas (Vigna unguiculata). J. Food Sci. 1990; 55: 151-153.

11 Wondimu A and NG Malleshi Development of weaning foods based on malted, popped, and roller-dried barley and chickpea. Food Nutr. Bull. 1996; 17: $169-174$. 
12 Prinyawiwatkul W, Beuchat LR, McWatters KH and RD Phillips Functional properties of cowpea (Vigna unguiculata) flour as affected by soaking, boiling, and fungal fermentation. J. Agric. Food Chem. 1997; 45: 480-486.

13 Evans RJ and MH Kerr Protein isolation, extraction and precipitation of nitrogenous constituents of dry navy beans (Phaseolus vulgaris). J. Agric. Food Chem. 1963; 11: (1), 26 -29.

14 Hang YD, Steinkraus KH and LR Hacker Comparative studies on the nitrogen solubility of mung beans, pea beans and red kidney beans. J. Food Sci. 1970; 35: (3), 318-320.

15 Fan TY and FW Sosulski Dispersibility and isolation of protein from legume flours. Can. Inst. Food Sci. Technol. J. 1974; 7: 256-259.

16 Khan RI, Gatehouse JA and D Boulter The seed proteins of cowpea (Vignaunguiculata-L Walp). J. Exp Bot. 1980; 31: (125), 1599-1611

17 Sumner AK, Nielsen MA and CG Youngs Production and evaluation of pea protein isolate. J. Food Sci. 1981; 46: (2), 364-366, 372.

18 Jackson JC, Ng PKW, Uebersax MA, Bennink MR and GL Hosfield Optimizationof the aqueous extraction of proteins from cowpeas (Vigna unguiculata). Annual Meeting of the American Association of Cereal Chemists (AACC), 1997.

19 AOAC. Association of Official Analytical Chemists. Official Methods of Analysis of the Association of Official Analytical Chemists. AOAC, Washington, D.C., 2006.

20 Bidlingmeyer BA, Cohen SA, Tarvin TL and BA Frost New, rapid, highsensitivity analysis of amino acids in food type samples. J. Assoc. Off. Anal. Chem. 1987; 70: (2), 241-247.

21 Cohen SA, Tarvin TL and BA Bidlingmeyer Proteins: Structure and Function. New York, Plenum Press. 1987, 207-213.

22 Occeña LG Processing strategies to improve dry bean (Phaseolus vulgaris) digestibility and food utilization. Ann Arbor MI, University Microfilms 9512117. 1997; 1-257.

23 McDonough FE, Sarwar G, Steinke FH, Slump P, Garcia S and S Boisen In-vitro assay for protein digestibility: Inter-laboratory study. J. Assoc. Off. Anal. Chem. 1990; 73: (4), 622-625.

24 Young VR and PL Pellett Protein evaluation, amino acid scoring and the Food and Drug Administration's Food Labelling Regulations. J. Nutri. 1991; 121: 145-150. 
25 Pettersson A, Lindberg JE, Thomke S and BO Eggum Nutrient digestibility and protein quality of oats differing in chemical composition evaluated in rats and by an in technique. Ani Feed Sci and Tech. 1996; 62: 2-4, 203-213.

26 Wolzak A, Bressani R and RG Brenes A comparison of in vivo and in vitro estimates of protein digestibility of native and thermally processed vegetable proteins. Plant Foods for Hum Nutri. 1981; 31: 1, 3.

27 Rozan P, Lamghari R, Linder M, Villaume C, Fanni J, Parmentier M, Méjean L?? In Vivo and in Vitro Digestibility of Soybean, Lupine, and Rapeseed Meal Proteins after various technological processes. J Agric. Food Chem. 1997; 45: (5), 1762 -1769.

28 King TP, Pusztai A and EMW Clarke Kidney bean (Phaseolus vulgaris) lectin induced lesions in rat small intestine: 3 Ultrasound Studies. J. Comp Path. 1980; 92: 357-373.

29 Mensa-Wilmott YR, Phillips D and JL Hargrove Protein quality evaluation of cowpea-based extrusion cooked cereal/legume weaning mixtures. $J$. Nutr Res. 2001; 21: (6), 849-857.

30 Yañez E, Lobos P, Díaz LG and D Ballester Effect of roasting on the chemical composition and protein quality of Lupin Seeds (Lupinus albus cv Multolupa). J. Food Sci. 1986; 51: (5), 1235-1238. 